Jumal Matematika dan Aplikasi
ISSN:2302-4224
Je Oa r n al ho m e pa g e: https:/lejournal.unsrat.ac.id/index.php/decartesian

\title{
Regresi Logistik Multinomial Untuk Menentukan Faktor- Faktor Yang Mempengaruhi Pilihan Perguruan Tinggi Pada Siswa SMA dan SMK di Pulau Karakelang Kabupaten Kepulauan Talaud
}

\author{
Meykel M. Tulong1, Mans Mananohas ${ }^{1}$, Charles E. Mongi ${ }^{{ }^{*}}$ \\ ${ }^{1}$ Jurusan Matematika-Fakultas Matematika dan Ilmu Pengetahuan Alam-Universitas Sam Ratulangi Manado, Indonesia \\ *Corresponding author : charlesmongi@unsrat.ac.id
}

\begin{abstract}
A B S T R A K
Perbedaan pilihan pada siswa SMA/SMK setelah menempuh jenjang pendidikan, ipengaruhi oleh berbagai macam faktor. Tujuan penelitian ini yaitu untuk melihat faktor-faktor yang memiliki hubungan serta berpengaruh signifikan terhadap pilihan perguruan tinggi oleh siswa SMA/SMK, serta melihat adanya perbedaan antara hasil observasi dengan hasil prediksi pada model logit yang terbentuk. Berdasarkan hasil uji kesesuaian model didapat bahwa tidak ada perbedaan model antara hasil observasi dengan hasil prediksi, sehingga model tersebut dapat digunakan dimana faktor-faktor yang berpengaruh signifikan terhadap jenis pilihan Universitas di luar Sulawesi Utara yaitu sekolah yang berasal dari SMA NEGERI 1 RAINIS, siswa dengan satu saudara dan dua saudara, penghasilan orang tua/bulan rendah. Sedangkan faktor-faktor yang berpengaruh signifikan terhadap jenis pilihan Universitas Swasta di Sulawesi Utara yaitu siswa yang memiliki dua saudara, pekerjaan ayah pegawai dan atau pekerjaan ibu swasta.
\end{abstract}

\author{
INFO ARTIKEL \\ Diterima : : 10 September 2018 \\ Diterima setelah revisi $: 18$ September 2018 \\ Tersedia online $\quad: 30$ September 2018
}

\section{Kata Kunci:}

SMA, SMK

Kepulauan Talaud

Regresi logistik multinomial

Skala nominal

\section{PENDAHULUAN}

Setelah menempuh pendidikan sekolah menengah atas siswa dihadapkan pada pilihan, baik itu melanjutkan ke perguruan tinggi, bekerja dan lain-lain sebagainya. Ada banyak perbedaan pilihan yang dipengaruhi oleh faktor-faktor baik faktor dari dalam diri siswa ataupun dari luar siswa itu sendiri. Sehubungan dari uraian diatas diperlukan analisis untuk melihat hubungan antara variabel respon yang bersifat lebih dari dua kategori (multinomial) dengan variabel prediktor yang bersifat kategori maupun kontinu serta berskala nominal dan ordinal maka digunakan analisis regresi logistik multinomial untuk menyelesaikannya.

Pada penelitian sebelumnya yang berkaitan, digunakan regresi logistik ordinal untuk mengetahui hubungan antara kepuasan penumpang pesawat terbang terhadap kualitas pelayanan di bandara Internasional Manado, dengan variabel respon berbentuk kategori yaitu kategori tingkat kepuasan yang diantaranya kurang baik dengan kategori $o$, cukup dengan kategori 1 dan baik dengan kategori 2 [1]. Penelitian yang lain tentang deskripsi tingkat kepuasan masyarakat terhadap pelayanan di satuan penyelenggara administrasi surat izin mengemudi kepolisian resor kota Manado juga menggunakan regresi logistik ordinal dengan variabel respon berbentuk kategori dan lebih dari dua kategori diantaranya tidak puas dengan kategori 0 , puas dengan kategori 1 dan sangat puas dengan kategori 2 [2].

\section{REGRESI}

\subsection{Regresi Logistik}

Regresi logistik merupakan analisis yang digunakan untuk melihat hubungan antara variabel respon yang bersifat kategorik (kualitatif) dan variabel-variabel prediktor yang bersifat nominal atau ordinal (kualitatif) maupun interval atau rasio (kuantitatif) [3]..

\subsection{Skala Nominal}

Skala nominal dapat dinyatakan sebagai ukuran yang tidak sebenarnya. Skor untuk setiap satuan pengamatan atau individu hanya merupakan tanda atau simbol yang menunjukkan kedalam kelompok atau kelas mana individu tersebut dikelompokkan. 
Misalnya, jenis kelamin dengan skor "1" untuk laki-laki dan "o" untuk perempuan. Skor 1 dan o hanya untuk membedakan antara kelompok yang satu dengan yang lainnya. Urutan, selisih, jumlah, dan operasi hitung lainnya terhadap data skala nominal tidak mempunyai arti [4].

\subsection{Skala Ordinal}

Skala ordinal menunjukkan urutan (peringkat, tingkatan, atau ranking) yang berfungsi juga sebagai pengelompokkan. Misalnya tingkat pendidikan dengan kategori "o" untuk SD, "1" untuk SLTP, dan "2" untuk SLTA. Skala ini memungkinkan peneliti untuk mengurutkan respondennya dari tingkat paling rendah ke tingkat paling tinggi atau sebaliknya [4].

\subsection{Uji Independensi}

Uji independensi dilakukan untuk mengetahui ada atau tidaknya hubungan antara variabel respon dengan variabel prediktor [5]. Pengujian tersebut dilakukan dengan melihat nilai Chi-Square. Uji independensi dapat dilihat pada persamaan 1.

$$
\chi^{2}=\sum_{i=1}^{n} \frac{\left(o_{i j}-e_{i j}\right)^{2}}{e_{i j}}
$$

$o_{i j}=$ nilai observasi pada baris ke- $i$ dan kolom ke- $j$

$e_{i j}=$ nilai ekspektasi/harapan pada baris ke- $i$ dan kolom ke-j

dengan :

$e_{i j}=\frac{\sum\left(o_{i .}\right) \cdot \sum\left(o_{. j}\right)}{\sum o_{i j}}$

\subsection{Analisis Regresi Logistik Multinomial}

Analisis regresi logistik multinomial merupakan regresi logistik yang digunakan saat variabel respon bersifat polychotomous atau multinomial, berskala nominal dan ordinal dengan lebih dari dua kategori. Model regresi untuk variabel respon yang lebih dari dua kategori harus memperhatikan skala pengukuran [6]. Pada penelitian ini menggunakan model regresi logistik dengan variabel respon berskala nominal. Fungsi probabilitas regresi logistik untuk masingmasing kategori dapat di lihat pada persamaan 3, 4, dan 5 .

$$
\begin{aligned}
& \pi_{1}(x)=P\left(Y=1 \mid=\frac{\exp g_{1}(x)}{1+\exp g_{1}(x)+\exp g_{2}(x)}\right. \\
& \pi_{2}(x)=P(Y=2 \mid x)=\frac{\exp g_{2}(x)}{1+\exp g_{1}(x)+\exp g_{2}(x)} \\
& \pi_{3}(x)=P(Y=3 \mid x)=\frac{1}{1+\exp g_{1}(x)+\exp g_{2}(x)}
\end{aligned}
$$

Cumulative Logit Models didapatkan dengan membandingkan peluang kumulatif yaitu peluang kurang dari atau sama dengan kategori respon ke-j pada $p$ variabel prediktor yang dinyatakan dalam vektor $x_{i} P\left(Y \leq j \mid x_{i}\right)$, dengan peluang lebih besar dari kategori respon ke-j, $P\left(Y>j \mid x_{i}\right) \quad$ ([6]. Rumus cumulative logit models dapat dilihat pada persamaan 6.

$$
\text { Logit } P\left(Y \leq j \mid x_{i}\right)=\log \left(\frac{P\left(Y \leq j \mid x_{i}\right)}{P\left(Y>j \mid x_{i}\right)}\right)
$$

Sehingga secara umum, bentuk dari fungsi logit dengan variabel respon yang terdiri dari lebih dari dua kategori adalah seperti pada persamaan 7 .

$$
\begin{aligned}
& g_{j}(x)=\log \left(\frac{P\left(Y \leq j \mid x_{i}\right)}{P\left(Y>j \mid x_{i}\right)}\right)=\beta_{j 0}+\beta_{j 1} X_{1}+\beta_{j 2} X_{2}+\cdots+ \\
& \beta_{j p} X_{p}
\end{aligned}
$$

\subsubsection{Pengujian Parameter Secara Serentak}

Pengujian secara serentak digunakan untuk mengetahui pengaruh variabel prediktor terhadap variabel respon dalam model secara bersama-sama. Uji serentak menggunakan uji likelihood dapat dilihat pada persamaan 8 [6].

$$
\begin{aligned}
& G^{2}=-2 \ln \left[\frac{\left(\frac{n_{1}}{n}\right)^{n_{1}}\left(\frac{n_{2}}{n}\right)^{n_{2}}\left(\frac{n_{3}}{n}\right)^{n_{3}}}{\prod_{i=1}^{n}\left[\pi_{1}\left(x_{i}\right)^{y_{1}} \pi_{2}\left(x_{i}\right)^{y_{2}} \pi_{3}\left(x_{i}\right)^{y_{3}}\right]}\right]= \\
& 2 \sum o_{i j} \log \left(o_{i j} / e_{i j}\right)
\end{aligned}
$$

\subsubsection{Pengujian Parameter Secara Parsial}

Pengujian parsial dilakukan untuk mengetahui apakah variabel prediktor berpengaruh signifikan atau tidak terhadap variabel respon secara tunggal. Uji ini dimaksudkan untuk melihat apakah suatu variabel prediktor layak masuk dalam model [7]. Uji parsial menggunakan uji wald dan dapat dilihat pada persamaan 9.

$$
W_{k}=\left(\frac{\widehat{\beta} k}{S \widehat{E}(\widehat{\beta} k)}\right)^{2}
$$

\subsubsection{Pengujian Kesesuaian Model}

Dari estimasi model regresi logistik yang telah diperoleh, selanjutnya dilakukan pengujian untuk kesesuaian model. Terdapat statistik uji yang digunakan untuk menguji kesesuaian model pada regresi logistik yaitu Goodness of Fit [6]. Statistik Goodness of Fit dapat di lihat pada persamaan 10.

$\hat{C}=\sum_{i=1}^{k} \frac{\left(O_{i}-n_{i} \widehat{\pi}_{i}\right)^{2}}{n_{i} \widehat{\pi}_{i}\left(1-\widehat{\pi}_{i}\right)}$

Interpetasi model dalam regresi logistik menggunakan nilai odds ratio yang menunjukkan perbandingan berapa kali lipat kenaikan atau penuruan angka kejadian $\mathrm{Y}=j$ terhadap $\mathrm{Y}=1$ sebagai kategori pembanding jika nilai variabel prediktor (x) berubah sebesar nilai tertentu [6], sebagaimana persamaan 11.

$\psi_{a b}=O R_{j}(a, b)=\frac{P(Y=j \mid x=a) / P(Y=1 \mid x=a)}{P(Y=j \mid x=b) / P(Y=1 \mid x=b)}$

Hubungan antara odds ratio terhadap parameter $\operatorname{model}(\beta)$ a dalah $: \psi_{a b}=\exp (\hat{\beta})$.

\subsection{Faktor-Faktor yang diduga Mempengaruhi Siswa Terhadap Pemilihan Perguruan Tinggi.}

Pada penelitian sebelumnya, faktor-faktor yang diduga berpengaruh untuk menentukan sekolah lanjutan diantarannya [8]:

- Jenis kelamin yang terdiri dari 2 kategori yaitu laki-laki dan perempuan.

- Asal sekolah yang dalam penelitian ini terdiri dari 11 kategori dimana SMA sebanyak 7 sekolah dan SMK sebanyak 4 sekolah. 
- Nilai Rata-Rata Semester (disesuaikan dengan penelitian).

- Banyak saudara (yang masih bersekolah).

- Pekerjaan orang tua, terdiri dua kategori yaitu Pekerjaan Ayah dan Pekerjaan ibu.

- Pendapatan orang tua yaitu penghasilan yang diterima orang tua dalam bentuk uang dari hasil kerja. Disesuaikan dengan kesimpulan BPS, yang dibedakan menjadi 4 kategori yaitu : Penghasilan Rendah, Penghasilan Sedang, Penghasilan Tinggi dan Penghasilan Sangat Tinggi.

- Pendidikan terakhir orang tua terdiri dari 2 kategori yaitu Pendidikan Ayah dan Pendidikan Ibu.

\section{METODOLOGI PENELITIAN \\ 3.1. Sumber Data}

Data diambil dari siswa SMA dan SMK kelas XII yang ada di Kabupaten Kepulauan Talaud, Provinsi Sulawesi Utara khususnya di pulau Karakelang dengan menggunakan kuisioner, dimana Sekolah Menengah Atas (SMA) sebanyak 7 diantaranya SMA N 2 Beo SMA N 1 Rainis, SMA Advent Ambia, SMA N 1 Sambuara, SMA N 1 Essang, SMA N 1 Gemeh dan Sekolah Menengah Kejuruan (SMK) sebanyak 4 sekolah diantaranya SMKN 5 Talaud, SMK N 1 Melongguane, SMK N 3 Talaud, SMK N 4 Talaud.

\subsection{Waktu dan Tempat Penelitian}

Penelitian dilaksanakan di Kabupaten Kepulauan Talaud Provinsi Sulawesi Utara khususnya di pulau Karakelang selama kurang lebih satu bulan yaitu antara tanggal 12 Januari sampai 12 Februari tahun 2018.

\subsection{Variabel Penelitian}

1. Variabel Respon (Y) berskala nominal dan terdiri dari 3 kategori, yaitu Universitas di Luar Sulawesi Utara, Universitas Swasta di Sulawesi Utara dan Universitas Negeri di Sulawesi Utara.

2. Variabel Prediktor (X) terdiri dari 9 variabel, yaitu Jenis Kelamin (X1) berskala nominal, Asal Sekolah (X2) berskala nominal, Nilai Rata-rata Semester lima $\left(\mathrm{X}_{3}\right)$ skala ordinal, Banyak Saudara (X4) berskala nominal, Pekerjaan Ayah ( $\left.\mathrm{X}_{5}\right)$ berskala nominal, Pekerjaan Ibu (X6) berskala nominal, Penghasian Orang Tua/bulan (X7) berskala ordinal, Pendidikan Ayah (X8) berskala ordinal dan Pendidikan Ibu (X9) berskala ordinal.

\subsection{Metode Analisis}

Langkah-langkah yang dilakukan untuk menganalisis dalam kajian ini adalah.

1. Mendeskripsikan karakteristik pemilihan perguruan tinggi menggunakan statistika deskriptif.

2. .Menyeleksi variabel penelitian untuk melihat hubungan antara variabel prediktor terhadap variabel respon dengan menggunakan uji independensi dengan melihat nilai Chi-Square .

3. Melakukan uji parsial atau uji secara tunggal untuk mengetahui variabel yang berpengaruh signifikan secara tunggal.

4. Menginterpretasikan peluang masing-masing kategori secara tunggal berdasarkan odds ratio.
5. Melakukan uji serentak dengan menggunakan uji Likelihood Ratio atau uji $G^{2}$ untuk melihat secara serentak apakah variabel prediktor minimal ada ataukah tidak ada satu variabel yang berpengaruh signifikan terhadap model

6. Membentuk model logit pada masing-masing kategori respon di setiap model pada estimasi parameter secara serentak. Model logit bertujuan untuk membuat perbandingan antara kategori yang kurang dari $Y_{j}$ dengan kategori pembanding yaitu kategori yang lebih dari $Y_{j}$, dimana model tersebut akan menghasilkan fungsi probability untuk masing-masing kategori variabel respon. Untuk variabel respon $\left(Y_{j}\right)$ dengan tiga kategori akan menghasilkan dua model logistik.

7. Melakukan uji kesesuaian model dengan menggunakan uji Godness of Fit untuk melihat apakah model itu sesuai atau tidak antara prediksi dengan observasi.

8. Menyimpulkan suatu kasus dengan model regresi logistik multinomial yang telah diperoleh.

\section{HASIL DAN PEMBAHASAN}

4.1. Deskripsi Pilihan Perguruan Tinggi Pada Siswa SMA dan SMK di Kabupaten Kepulauan Talaud Provinsi Sulawesi Utara Tahun 2018

Setelah melakukan penelitian di Sekolah Menengah Atas (SMA) dan Sekolah Menengah Kejuruan (SMK) dimana yang menjadi objek penelitian yaitu siswa kelas XII dikarenakan siswa kelas XII tidak lama lagi akan menempuh jenjang yang lebih tinggi. Dari 7 Sekolah Menengah Atas dan 4 Sekolah Menengah Kejuruan didapat 188 responden melanjutkan pendidikan di perguruan tinggi.

\subsection{Hubungan Jenis Pilihan Perguruan Tinggi dengan Variabel Prediktor}

Untuk mengetahui hubungan antara jenis pilihan perguruan tinggi dengan variabel yang diduga berpengaruh yang diantaranya adalah jenis kelamin, asal sekolah, nilai rata-rata siswa, banyak saudara, pekerjaan ayah, pekerjaan ibu, penghasilan orang tua/bulan, pendidikan ayah dan pendidikan ibu maka digunakan uji independensi atau dengan melihat nilai Chi-Square $\left(\chi^{2}\right)$. Hasil uji independensi disajikan pada tabel $1 .$.

Tabel 1. Hasil Uji Independensi

\begin{tabular}{|c|l|c|r|r|r|c|}
\hline No & Variabel & $\mathrm{df}$ & \multicolumn{1}{c|}{$\chi_{\text {nitung }}$} & $\chi^{2}{ }_{\text {tabel }}$ & $P_{\text {value }}$ & Keputusan \\
\hline 1 & Jenis Kelamin & 2 & 0.271 & 4.605 & 0.873 & Terima $H_{0}$ \\
\hline 2 & Asal Sekolah & 20 & 51.80663 & 28.411 & 0.000 & Tolak $H_{0}$ \\
\hline 3 & Nilai Rata-rata & 2 & 3.821479 & 4.605 & 0.148 & Terima $H_{0}$ \\
\hline 4 & $\begin{array}{l}\text { Banyak } \\
\text { Saudara }\end{array}$ & 8 & 18.26323 & 13.361 & 0.019 & Tolak $H_{0}$ \\
\hline 5 & $\begin{array}{l}\text { Pekerjaan } \\
\text { ayah }\end{array}$ & 6 & 17.30757 & 10.644 & 0.008 & Tolak $H_{0}$ \\
\hline 6 & Pekerjaan Ibu & 4 & 14.78941 & 7.779 & 0.005 & Tolak $H_{0}$ \\
\hline 7 & $\begin{array}{l}\text { Penghasilan } \\
\text { orang Tua }\end{array}$ & 6 & 22.64646 & 10.644 & 0.001 & Tolak $H_{0}$ \\
\hline 8 & $\begin{array}{l}\text { Pendidikan } \\
\text { Ayah }\end{array}$ & 10 & 26.98403 & 15.987 & 0.003 & Tolak $H_{0}$ \\
\hline 9 & $\begin{array}{l}\text { Pendidikan } \\
\text { Ibu }\end{array}$ & 6 & 6.719893 & 10.644 & 0.348 & Terima $H_{0}$ \\
\hline
\end{tabular}

Dengan melihat Tabel 1 dan berdasarkan persamaan 1, menunjukan bahwa pada variabel jenis kelamin nilai $\chi_{\text {hitung }}^{2}=0.271$ kurang dari $\chi_{\text {tabel }}^{2}=$ 4.605 dan $P_{\text {value }}=0.873$ lebih dari $\alpha=0.1$ sehingga menghasilkan keputusan Terima $H_{0}$ atau dapat 
disimpulkan dengan tingkat kepercayaan 90\% variabel jenis kelamin tidak ada hubungannya dengan pemilihan perguruan tinggi. Berikutnya Variabel asal sekolah memiliki nilai $\chi_{\text {hitung }}^{2}=51.80663$ yang lebih dari $\chi_{\text {tabel }}^{2}=28.411$ dan $P_{\text {value }}=0.000$ yang kurang dari $\alpha=0.1$ sehingga menghasilkan keputusan Tolak $H_{0}$ atau dapat dikatakan terdapat hubungan antara variabel asal sekolah terhadap jenis pilihan perguruan tinggi. Nilai Rata-rata memiliki nilai $\chi_{\text {hitung }}^{2}=3.821479$ yang kurang dari $\chi^{2}{ }_{\text {tabel }}=4.605$ dan $P_{\text {value }}=0.148$ lebih dari $\alpha=0.1$ itu artinya menghasilkan keputusan Terima $H_{0}$, sehingga dapat disimpulkan dengan tingkat kepercayaan 90\% variabel nilai rata-rata tidak ada hubungannya dengan pemilihan perguruan tinggi. Selanjutnya variabel Banyak Saudara dengan nilai $\chi_{\text {hitung }}^{2}=18.26323$ yang lebih dari $\chi^{2}{ }_{\text {tabel }}=13.361$ dan $P_{\text {value }}=0.019$ yang kurang dari $\alpha=0.1$, menghasilkan keputusan Tolak $H_{0}$, sehingga dapat disimpulkan dengan tingkat kepercayaan $90 \%$ terdapat hubungan antara variabel banyak saudara terhadap pemilihan perguruan tinggi oleh siswa/i.

\subsection{Pemodelan Pola Pilihan Perguruan Tinggi}

Dari sembilan variabel hanya enam variabel yang memiliki hubungan akan digunakan dalam analisis selanjutnya atau dalam pembuatan model, yaitu asal sekolah, banyak saudara, pekerjaan ayah, pekerjaan ibu, penghasilan orang tua/bulan dan pendidkan ayah.

Tabel 2. Hasil Pengujian Likelihood

\begin{tabular}{|c|c|c|c|c|}
\hline \multirow{2}{*}{ Model } & \multicolumn{4}{|c|}{ Uji Rasio Likelihood } \\
\cline { 2 - 5 } & $G^{2}$ & $\mathrm{df}$ & $\chi_{\text {tabel }}^{2}$ & $P_{\text {value }}$ \\
\hline Final & 99.506 & 54 & 67.67 & 0.000 \\
\hline
\end{tabular}

Berdasarkan hasil uji $G^{2}$, mengacu pada Tabel 2, menunjukan bahwa nilai dari $G^{2}=99.506$ yang lebih dari nilai $\chi_{\text {tabel }}^{2}$ dan nilai $P_{\text {value }}=0.000$ yang kurang dari $\alpha=0.1$ sehingga menghasilkan keputusan tolak $H_{0}$ atau dapat disimpulkan bahwa dengan menggunakan tingkat kepercayaan sebesar 90\% terdapat minimal ada satu variabel prediktor yang berpengaruh signifikan secara serentak terhadap jenis pilihan perguruan tinggi pada siswa SMA/SMK di Kabupaten Kepulauan Talaud Provinsi Sulawesi Utara. model logit sebagai berikut.

$$
\begin{aligned}
g_{1}(x)=\mathbf{1 6 . 8 6 3 +} & 2.917 x_{2}(2)-2.226 x_{4}(1) \\
+ & 0.853 x_{5}(3)+0.485 x_{6}(1) \\
- & 3.718 x_{7}(1)-17.726 x_{8}(3) \\
g_{2}(x)=\mathbf{1 7 . 3 7 3 +} & 5.932 x_{2}(8)-2.944 x_{4}(2) \\
- & 4.029 x_{5}(2)+3.216 x_{6}(1) \\
- & 4.056 x_{7}(1)-33.585 x_{8}(3)
\end{aligned}
$$

$g_{1}(x)=$ Model Logit[1] adalah pilihan universitas di luar Sulawesi Utara

$g_{2}(x)=$ Model Logit[2] adalah pilihan universitas Swasta di Sulawesi Utara.

Dari dua model logit diatas dapat diperoleh fungsi probabilitas secara serentak untuk masing-masing kategori jenis pemilihan perguruan tinggi oleh siswa yang ada di Kabupaten Kepulauan Talaud Provinsi Sulawesi Utara. Berikut fungsi probabilitas secara serentak untuk masing-masing kategori tersebut.

$$
\begin{aligned}
& \pi_{1}(x)=\frac{\operatorname{expg}_{1}(x)}{1+\operatorname{expg}_{1}(x)+\operatorname{expg}_{2}(x)} \\
& =\frac{\exp (-2.55)}{1+\exp (-2.55)+\exp (-18.09)} \\
& =0.07 \\
& \pi_{2}(x)=\frac{\operatorname{expg}_{2}(x)}{1+\operatorname{expg}_{1}(x)+\operatorname{expg}_{2}(x)} \\
& =\frac{\exp (-18.09)}{1+\exp (-2.55)+\exp (-18.09)} \\
& =0.00 \quad 1 \\
& \pi_{3}(x)=\frac{1}{1+\operatorname{expg}_{1}(x)+\operatorname{expg}_{2}(x)} \\
& =\frac{1+\exp (-2.55)+\exp (-18.09)}{1+93}
\end{aligned}
$$

dengan : $\sum_{i=1}^{n} \pi_{n}(x)=1$

Tabel 3. Hasil Uji Kesesuaian Model

\begin{tabular}{|l|c|c|c|c|}
\hline \multirow{2}{*}{} & \multicolumn{4}{|c|}{ Uji Rasio Likelihood } \\
\cline { 2 - 5 } & $\begin{array}{c}\text { Chi- } \\
\text { square }\end{array}$ & $d f$ & $\chi^{2}{ }_{\text {tabel }}$ & $P_{\text {value }}$ \\
\hline Pearson & 164.518 & 180 & 204.703 & 0.790 \\
\hline Devians & 79.227 & 180 & 204.703 & 1.000 \\
\hline
\end{tabular}

Berdasarkan statistik uji Kesesuaian Model dan mengacu pada Tabel 3 nilai Pearson adalah 164.518 yang kurang dari nilai $\chi_{\text {tabel }}^{2}$ sebesar 204.703 dan nilai $p$-value sebesar 0.790 yang lebih dari $\alpha=0.1$ yang berarti Terima $H_{0}$ sehingga dapat disimpulkan bahwa dengan tingkat kepercayaan sebesar 90\% maka model yang dihasilkan sesuai (Tidak ada perbedaan antara hasil observasi dengan hasil prediksi) sehingga model tersebut dapat digunakan.

\section{KESIMPULAN}

Dengan melihat analisis yang telah didapat fungsi probabilitas untuk masing-masing variabel respon yakni $\pi_{1}(x)=0.07, \pi_{2}(x)=0.00$ dan $\pi_{3}(x)=0.93$. Ini berarti dari tiga kategori variabel respon peluang pilihan siswa yang paling tinggi yaitu Universitas Negeri di Sulawesi Utara dengan peluang 0.93 selanjutnya secara berturut-turut yaitu Universitas di luar Sulawesi Utara dengan peluang 0.07 dan Universitas Swasta yang ada di Sulawesi Utara dengan peluang 0.00.

Faktor-faktor yang mempengaruhi pilihan siswa terhadap universitas di Luar Sulawesi Utara diantaranya siswa yang berasal dari SMAN 1 Rainis, siswa yang memiliki satu saudara dan dua saudara, siswa yang penghasilan orang tua/bulannya rendah. Sedangkan faktor-faktor yang berpengaruh signifikan terhadap siswa yang memilih perguruan tinggi Swasta di Sulawesi Utara, yaitu siswa yang memiliki dua saudara, siswa yang pekerjaan ayahnya swasta dan siswa yang pekerjaan ibunya swasta.

\section{DAFTAR PUSTAKA}

[1] Paputungan, N., Y, Langi., dan J, Prang. 2016. Analisis Regresi Logistik Ordinal Pada Tingkat Kepuasan Pengguna Jasa Terhadap Pelayanan di Bandara Internasional Sam RatulangiManado. Jurnal de Cartesian 5(2) : 73-79 
[2] Biri, V., C, Mongi., dan M, Mananohas. 2017. Deskripsi Tingkat Kepuasan Masyarakat Terhadap Pelayanan Di Satuan Penyelenggara Administrasi Surat Izin Mengemudi Kepolisian Resor Kota Manado Menggunakan Regresi Logistik Ordinal. Jurnal Decartesian. 17(2) : 2-8

[3] Sepang, F., H, Komalig., dan D, Hatidja. 2012. Penerapan Regresi Logistik Untuk Menentukan Faktor-Faktor Yang Mempengaruhi Pemilihan Jenis Alat Kontrasepsi Di Kecamatan Modayag Barat. Jurnal MIPA Unsrat Online. 1(1) :1-5

[4] Tiro, M.A. 2000. Analisis Regresi Dengan Data Kategori. Badan Penerbit Universitas Negeri Makassar, Makassar.

[5] Walpole, R. E. 1995. Pengantar Statistik Edisi ke3. Diterjemahkan oleh: Bambang Sumantri, Gramedia Pustaka Utama, Jakarta.

[6] Hosmer D. W and S. Lemeshow, 2000. Applied Logistic Regression. John Wiley and Sons, New York.

[7] Agresti, A. 2002. Categorical Data Analysis, John Wiley and Sons, Inc. New York.

[8] Subekti, 2014. Model Regresi Logistik Multinomial Untuk Menentukan Pilihan Sekolah Lanjutan Tingkat Atas Pada Siswa SMP. Universitas Brawijaya Malang.

Meykel M. Tulong (tulongmeykel@gmail.com) Lahir di Girian, Menempuh pendidikan tinggi Jurusan Matematika, $\quad$ FMIPA, Universitas Sam Ratulangi Manado pada tahun 2014 Tahun 2018 adalah tahun terakhir ia menempuh studi. Makalah ini merupakan hasil penelitian skripsinya yang dipublikasikan.

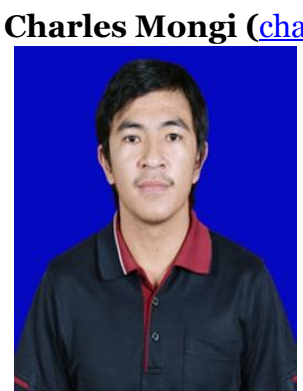

\section{rlesmongi@unsrat.ac.id)}

Lahir di Tondano, 4 Januari 1984. Pada tahun 2006 memperoleh gelar Sarjana Matematika di Universitas Sam Ratulangi, Manado. Melanjutkan di Institut Pertanian Bogor tahun 2011 dan mendapatkan Gelar Magister bidang Statistika Matematika pada tahun 2014. Menjadi pengajar di jurusan Matematika, Fakultas Matematika dan Ilmu Pengetahuan Alam, Universitas Sam Ratulangi Manado pada tahun 2010.

Mans Mananohas (mansmananohas@yahoo.com)

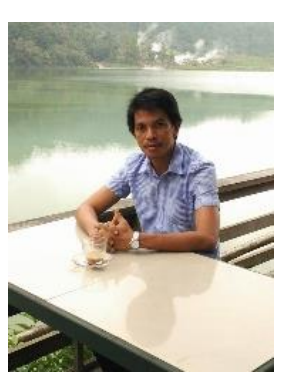
Lahir di Sangihe, 11 Juni 1984 Pada tahun 2006 memperoleh gelar Sarjana di jurusan Matematika Fakultas Matematikan dan Ilmu Pengetahuan Alam, Universitas Sam Ratulangi, Manado. Mendapatkan Gelar Magister di Institut Teknologi Bandung (ITB) pada tahun 2013. Pada tahun 2008 menjadi pengajar di jurusan Matematika Fakultas Matematika dan Ilmu Pengetahuan Alam Universitas Sam Ratulangi. Bidang keahlian yaitu Analisis dan Aljabar. 